\title{
PEMISAHAN PADATAN LUMPUR TINJA PADA UNIT SOLID SEPARATION CHAMBER (SSC)
}

\author{
Dwi Wulandari*1) ${ }^{* 1}$ dan Welly Herumurti ${ }^{1)}$ \\ ${ }^{1)}$ Departemen Teknik Lingkungan,Institut Teknologi Sepuluh Nopember (ITS), \\ Kompleks Kampus ITS, Sukolilo, Surabaya, 60111 \\ ${ }^{*}$ E-mail: wulandwi91@ gmail.com
}

\begin{abstract}
Abstrak
Lumpur tinja merupakan sumber pencemar yang mengandung padatan, material organik dan mikroorganisme patogen. Lumpur tinja memiliki karakteristik umum diantaranya TSS 4.000-100.000 mg/L, COD 20.000-50.000 mg/L, BOD 5 6.000-7.600 mg/L, dan total coliform $10^{5}-10^{10} \mathrm{CFU} / 100 \mathrm{~mL}$. Tangki septik kedap air merupakan salah satu solusi yang digunakan oleh masyarakat dalam pengolahan lumpur tinja. Tangki septik mengendapkan padatan dan mendegradasi lumpur tinja secara anaerobik, tetapi hasil degradasi masih mengandung zat organik maupun patogen yang membahayakan lingkungan. Salah satu unit pengolahan lumpur tinja dari tangki septik adalah Solid Separation Chamber (SSC) yang memisahkan padatan dan cairan. Proses di dalam unit SSC dipengaruhi oleh ketebalan lumpur, media filter, maupun konsentrasi TS. Hasil penelitian menunjukkan bahwa pada ketebalan $30 \mathrm{~cm}$ konsentrasi TS mempengaruhi proses di dalam unit SSC. Semakin besar konsentrasi TS yang masuk, maka semakin banyak filtrat yang dihasilkan dan penyisihan bahan organik, padatan tersuspensi, dan total coliform.
\end{abstract}

Kata kunci: Filtrasi, Lumpur Tinja, Media Pasir, SSC, Total Solid.

\begin{abstract}
Fecal sludge is a type of waste containing solids, organic materials and pathogenic organisms. The typical characteristics of fecal sludge include a TSS level of 4,000-100,000 mg/L, COD 20,000-50,000 mg/L, BOD 6,000-7,600 mg/L, and total coliform $10^{5}-10^{10} \mathrm{CFU} / 100 \mathrm{~mL}$. A watertight septic tank is one of the solutions used in communities in fecal sludge treatment. In a septic tank, solids settle, and fecal sludge degrades anaerobically, but the result of this degradation would still contain organic materials of pathogens that are dangerous to the environment. A way to treat septage from septic tank is by using a Solid Separation Chamber (SSC) that separates solids and liquid. The process in an SSC is affected by sludge thickness, filter media, and TS concentration. The study showed that at sludge thickness of $30 \mathrm{~cm}$, TS concentration influences the process in an SSC unit. The higher TS concentration of the incoming sludge, the more filtrate will be generated, and organic materials, suspended solids, and total coliform separated.
\end{abstract}

Keywords: Filtration, Fecal Sludge, Sand Media, SSC, Total Solid. 


\section{PENDAHULUAN}

Lumpur tinja merupakan sumber pencemar yang terdiri atas padatan yang terlarut di dalam air yang sebagian besar mengandung material organik. Beban organik yang besar menyebabkan lumpur tinja dapat mencemari air tanah. Tangki septik kedap air merupakan salah satu solusi yang digunakan oleh masyarakat untuk mengolah lumpur tinja yang dihasilkan. Tangki septik mampu mengendapkan padatan dan menyisihkan bahan organik secara anaerobik dengan bantuan mikroorganisme. Kandungan lumpur tinja setelah didegradasi dalam tangki septik umumnya mengandung TSS 6.000-17.500 $\mathrm{mg} / \mathrm{L}, \mathrm{BOD}_{5}$ 840-2600 mg/L, COD 1.200$7.800 \mathrm{mg} / \mathrm{L}$, dan total coliform $6,3 \times 10^{4}$ $6,6 \times 10^{5}$ CFU/100 mL (Kone dan Strauss, 2004), tetapi pengolahan ini belum efektif karena kandungan padatan, bahan organik, dan total coliform masih tinggi yang dapat membahayakan bagi kesehatan. Selain itu kapasitas tangki septik terbatas, idealnya setiap 2-5 tahun sekali harus dikuras dan dilakukan pengolahan lebih lanjut (Sudarmadji, 2013). Lumpur dari tangki septik tersebut diangkut oleh truk tinja dan diolah lebih lanjut di IPLT.

Salah satu pengolahan yang digunakan adalah Unit Solid Separation Chamber (SSC). SSC adalah unit pengolahan fisik yang memisahkan antara cairan dan padatan. Proses yang terjadi pada unit SSC adalah perpaduan antara sedimentasi, filtrasi, dekantasi, dan evaporasi. Lumpur tinja melalui media berpori dan padatan tertinggal di atas media filter, sedangkan cairan mengalir keluar melalui underdrain. Berdasarkan kondisi di lapangan durasi pengeringan lumpur tinja pada unit SSC belum terdapat SOP yang jelas (Dian dan Herumurti, 2016). Selain itu, belum terdapatnya informasi mengenai waktu dan kondisi optimum dalam pengurasan unit SSC. Pada penelitian ini dilakukan analisis efisiensi penyisihan TS dan TSS pada ketebalan lumpur konstan $30 \mathrm{~cm}$, pengaruh konsentrasi Total Solid yang masuk terhadap efisiensi penyisihan TSS dan TS, dan waktu optimal dalam proses dewatering.

\section{METODA}

\section{Analisis Karakteristik Awal}

Pada penelitian pendahuluan dilakukan analisis karakteristik awal lumpur tinja yang masuk ke unit SSC dan media filter berupa pasir Lumajang. Analisis media filter meliputi laju filtrasi dan ukuran media berbutir untuk menentukan ukuran media yang akan digunakan. Karakteristik lumpur tinja awal dan media pasir dapat dilihat pada Tabel 1 .

Tabel 1. Karakteristik Lumpur Tinja Awal dan Media Pasir

\begin{tabular}{ccc}
\hline Parameter & Satuan & Nilai \\
\hline \multicolumn{2}{c}{ Media Filter (Pasir Lumajang) } \\
\hline $\begin{array}{c}\text { Laju Filtrasi } \\
\text { Pasir Sebelum } \\
\text { Diayak } \\
\text { Laju Filtrasi }\end{array}$ & $\mathrm{m} / \mathrm{jam}$ & 0,169 \\
Diameter 0,2- & $\mathrm{m} / \mathrm{jam}$ & 0,085 \\
0,6 mm & & \\
Sg & - & 2,69 \\
Kadar Air & $(\%)$ & 0,42 \\
\hline \multicolumn{3}{c}{ Lumpur Tinja } \\
\hline Densitas & $\mathrm{kg} / \mathrm{m}^{3}$ & 1.001 \\
TS & $\mathrm{mg} / \mathrm{L}$ & 47.310 \\
TSS & $\mathrm{mg} / \mathrm{L}$ & 18.400 \\
COD & $\mathrm{mg} / \mathrm{L}$ & 18.000 \\
BOD & $\mathrm{mg} / \mathrm{L}$ & 7.708 \\
Amonium & $\mathrm{mg} / \mathrm{L}$ & 27.815 \\
Total Coliform & $\mathrm{MPN} / 100$ & $14 \times 10^{6}$ \\
\hline
\end{tabular}




\section{Tahap Persiapan Reaktor}

Pada penelitian ini menggunakan reaktor yang terbuat dari kayu dan dilapisi dengan plastik tebal yang berukuran $20 \mathrm{~cm} \mathrm{x} 40 \mathrm{~cm}$ x 100 $\mathrm{cm}$. Volume pengolahan pada reaktor adalah 27 L. Media yang digunakan yaitu media pasir 0,2 - 0,6 mm pada lapisan atas yang dicuci sebelum dipakai untuk menghilangkan lumpur yang menempel dan kerikil sebagai media penyangga pada lapisan bawah. Ketebalan media pasir yang digunakan $20 \mathrm{~cm}$ dan kerikil $20 \mathrm{~cm}$. Cairan dari hasil pemisahan dikumpulkan pada pipa ukuran 2,5 $\mathrm{cm}$ (1 inchi) dengan kemiringan 2\% dan dilengkapi dengan orifice ukuran $0,5 \mathrm{~cm}$ sebanyak 90 lubang. Reaktor dilindungi oleh atap agar tidak terkena air hujan.

\section{Pelaksanaan Penelitian}

Penelitian ini menggunakan variabel Total Solid dengan variasi $10 \mathrm{~g} / \mathrm{L}, 15 \mathrm{~g} / \mathrm{L}$, dan 20 $\mathrm{g} / \mathrm{L}$ sedangkan ketebalan lumpur konstan 30 $\mathrm{cm}$. Pelaksanaan penelitian ini dilakukan dengan pengukuran sampel filtrat yang keluar melalui underdrain dan lumpur yang tertinggal di atas media filter. Pengambilan sampel filtrat untuk analisis TS dan TSS, sedangkan lumpur untuk analisis kadar air dan suhu lumpur. Analisis filtrat dilakukan setiap hari selama filtrat keluar (13 hari), sedangkan lumpur dianalisis setiap hari selama 30 hari.

\section{Pengolahan Data}

Pengolahan data meliputi perhitungan akumulasi massa TS dan TSS yang keluar melalui filtrat, efisiensi TS dan TSS melalui filtrat, kadar air, suhu lumpur, pengaruh konsentrasi Total Solid terhadap efisiensi penyisihan TS dan TSS, dan pengaruh suhu lumpur terhadap efisiensi penyisihan TS dan TSS.

\section{HASIL DAN PEMBAHASAN}

\section{Analisis Penyisihan Total Solid (TS) pada Unit SSC}

Total solid yang dihasilkan menunjukan besarnya penyisihan padatan terlarut dan tersuspensi yang mampu dipisahkan oleh media filter. Sebesar $12 \%$ TS akan ikut dalam filtrat sedangkan sisanya akan terakumulasi dalam lumpur kering (Koottatep $d k k ., 2005$ ). Pengukuran penyisihan TS melalui filtrat selama filtrat keluar (13 hari). Gambar 1 menunjukkan akumulasi massa TS yang keluar melalui filtrat. Tujuan analisis ini adalah untuk mengetahui seberapa efektif media filter dalam menyisihkan zat padat tersuspensi dan terlarut dari lumpur tinja. Metode yang digunakan adalah gravimetri. Pola yang dihasilkan menunjukkan bahwa konsentrasi TS tidak mempengaruhi secara signifikan massa TS yang akan keluar melalui filtrat. Hal ini dibuktikan dari saling berpotongan/ bersinggungannya garis dari berbagai konsentrasi.

Hasil efisiensi TS filtrat pada Gambar 2 menunjukkan bahwa semakin pekat konsentrasi lumpur tinja yang dimasukkan semakin besar efisiensi yang dihasilkan. Konsentrasi yang pekat menunjukkan bahwa kandungan zat tersuspensi lebih besar dibandingkan pada konsentrasi encer.

Kandungan tersuspensi tersebut akan tertinggal pada media filter, sedangkan terlarut akan keluar dan terukur sebagai konsentrasi TS. Jadi dapat disimpulkan bahwa semakin pekat kandungan lumpur tinja yang dimasukkan ke unit SSC, maka akan meningkatkan efisiensi penyisihan zat padat. Berikut Gambar 1 menunjukkan akumulasi massa TS filtrat dan Gambar 2 besarnya penyisihan TS melalui filtrat. 


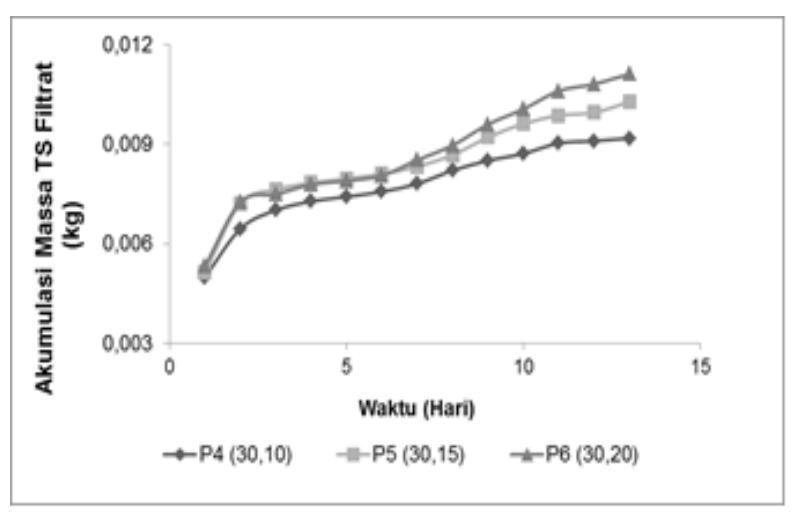

Gambar 1. Akumulasi Massa TS Filtrat

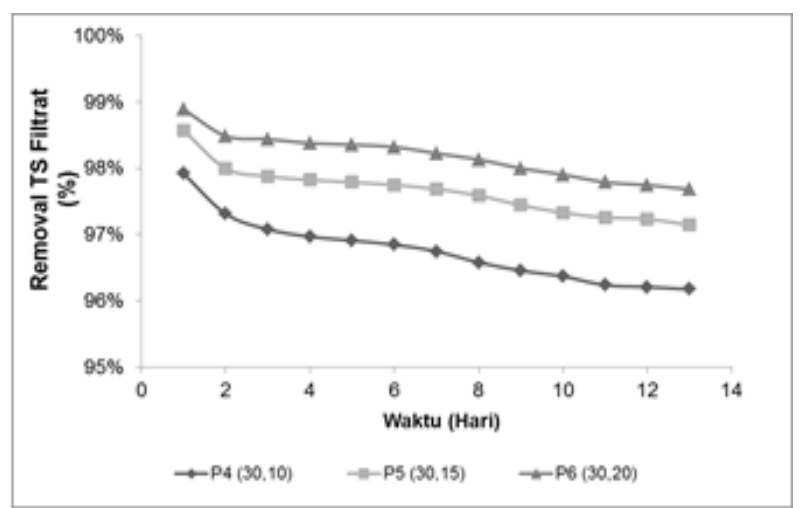

Gambar 2. Penyisihan TS melalui Filtrat

\section{Analisis Penyisihan Total Suspended Solid (TSS) pada Unit SSC}

Pengukuran TSS digunakan untuk mengetahui seberapa besar kemampuan media filter dalam penyisihan padatan tersuspensi. Pengukuran penyisihan TSS melalui filtrat selama 13 hari (filtrat keluar). Berikut Gambar 3 menunjukkan akumulasi massa TSS yang keluar melalui filtrat dan Gambar 4 efisiensi penyisihan TSS filtrat.

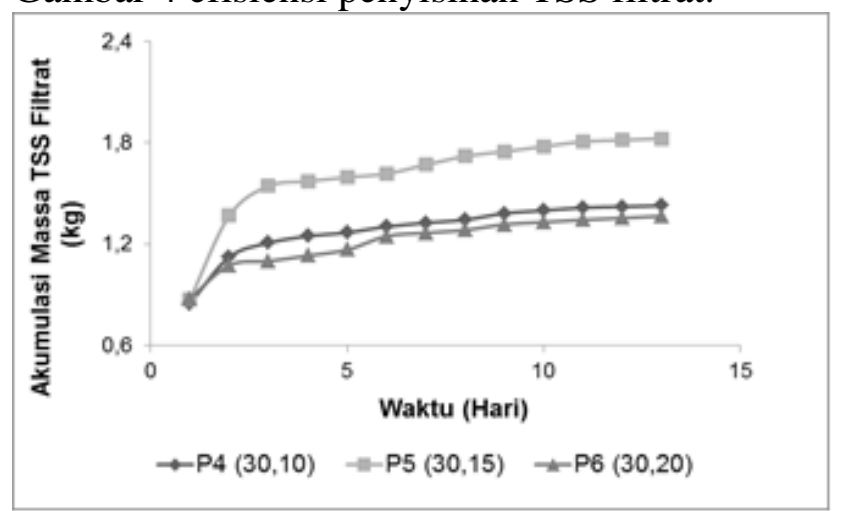

Gambar 3. Akumulasi Massa TSS Filtrat

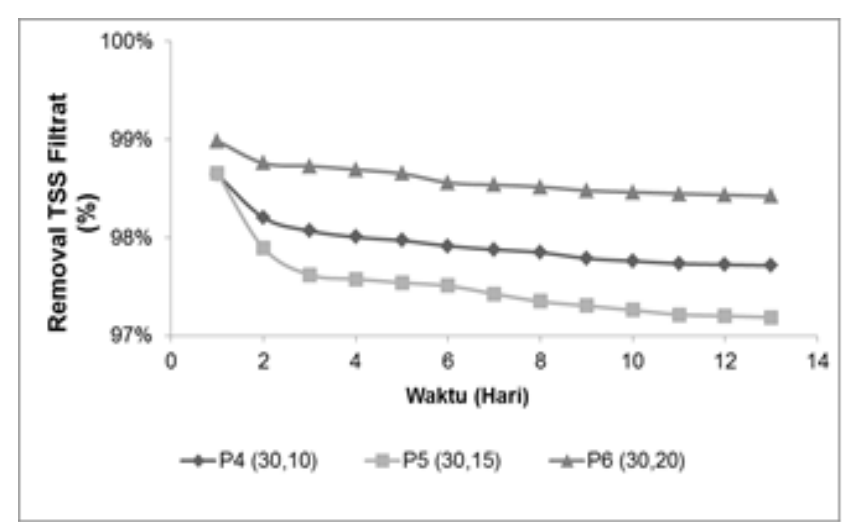

Gambar 4. Efisiensi Penyisihan TSS Filtrat

Konsentrasi TS yang rendah menyebabkan kandungan zat terlarut pada lumpur tinja lebih besar dibandingkan tersuspensi, sehingga zat tersuspensi akan tertinggal pada media dan zat terlarut akan keluar melalui filtrat. Akumulasi TSS filtrat menunjukkan bahwa pada konsentrasi paling pekat $20 \mathrm{~g} / \mathrm{L}$ memiliki akumulasi massa TSS pada filtrat yang paling kecil. Hal ini menunjukkan bahwa zat tersuspensi tersebut terakumulasi dan tertinggal di atas media filter, sedangkan zat terlarut keluar bersama dengan filtrat.

Konsentrasi TS yang pekat memiliki efisiensi yang lebih besar dibandingkan dengan yang encer. Hal ini sebanding dengan efisiensi pada TS (Gambar 2) yang menunjukkan bahwa semakin pekat lumpur tinja, maka semakin besar konsentrasi zat tersuspensi. Zat tersuspensi yang pekat cenderung untuk berkelompok sehingga mudah disaring dibandingkan berbentuk encer. Kandungan yang encer membuat media filter lebih lama untuk terbentuk clogging karena beban yang masuk lebih kecil (Koottatep $d k k .$, 2005).

\section{Pengaruh Konsentrasi Total Solid (TS) terhadap Penyisihan TS dan TSS Filtrat.}

Semakin besar konsentrasi TS, maka semakin pekat kandungan lumpur tinja. Pada Gambar 5 menunjukkan bahwa konsentrasi TS pada lumpur tinja mempengaruhi besarnya efisiensi penyisihan dari TS yang keluar dari filtrat. Hal ini dibuktikan dengan pola yang semakin menurun. Berikut Gambar 5 pengaruh 
konsentrasi TS lumpur tinja terhadap TS filtrat dan Gambar 6 pengaruh konsentrasi TS lumpur tinja terhadap TSS filtrat.

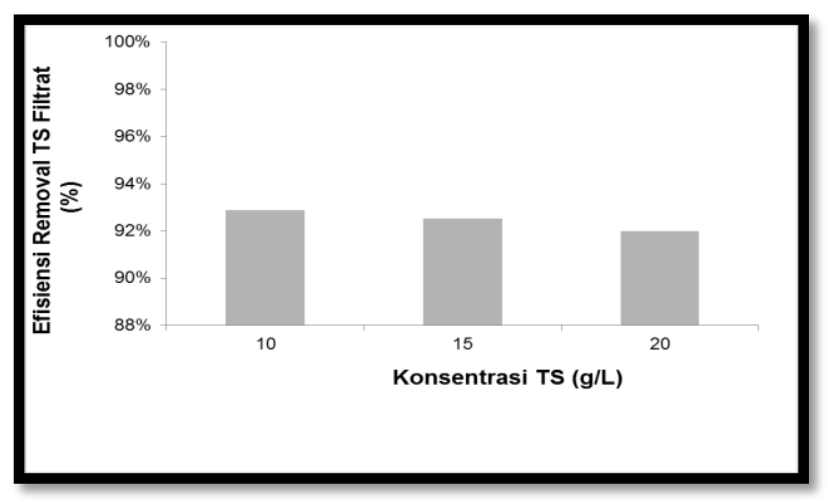

Gambar 5. Pengaruh Konsentrasi TS Lumpur Tinja terhadap TS Filtrat

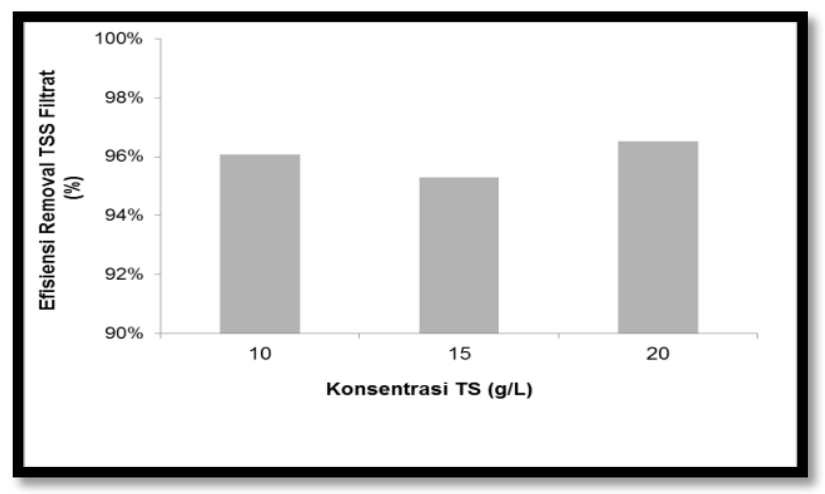

Gambar 6. Pengaruh Konsentrasi TS Lumpur Tinja terhadap TSS Filtrat

Pada konsentrasi TS pekat memiliki efisiensi yang menurun berdasarkan pola. Hal ini menunjukkan bahwa pada konsentrasi yang encer terdapat pengaruh dari mikroorganisme di dalam unit SSC yang menguraikan bahan organik secara anaerobik menjadi $\mathrm{CH}_{4}, \mathrm{H}_{2} \mathrm{O}$, $\mathrm{CO}_{2}$, dan $\mathrm{NH}_{3}$ (Bassan $d k k$. , 2014). Oleh sebab itu, nilai efisiensi semakin naik. Besarnya konsentrasi TS yang masuk tidak mempengaruhi besarnya penyisihan pada TSS.

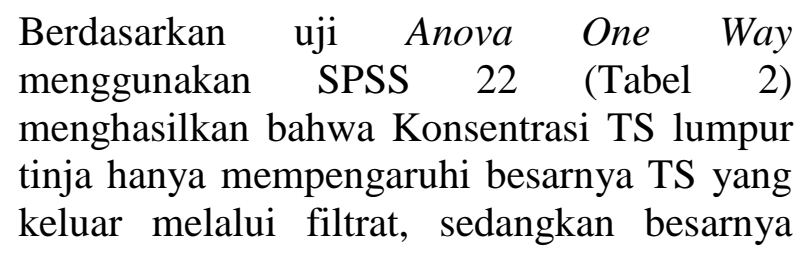

TSS tidak terpengaruh. hal ini sebanding dengan Gambar 5 dan Gambar 6. Hasil Anova menunjukkan berpengaruh jika memiliki derajat kepercayaan lebih dari $95 \%$

(Sig < 5\%). Hasil pengaruh konsentrasi TS lumpur tinja terhadap TS dan TSS filtrat dapat dilihat pada Tabel 2.

Tabel 2. Pengaruh Konsentrasi TS Lumpur Tinja Terhadap TS dan TSS Filtrat

\begin{tabular}{|cc|c|c|c|c|}
\hline & $\begin{array}{c}\text { Jumlah } \\
\mathrm{R}^{2}\end{array}$ & df & $\begin{array}{c}\mathrm{R} \\
\text { rata- } \\
\text { rata }\end{array}$ & $\mathrm{F}$ \\
\hline $\begin{array}{c}\text { TS } \\
\text { Filtrat }\end{array}$ & $\begin{array}{c}\text { Antar } \\
\text { Dalam } \\
\text { kelompok } \\
\text { Total }\end{array}$ &, 000 & 2 &, 000 & 6,237 \\
\hline Filtrat &, 002 & 114 &, 000 & \\
\hline & $\begin{array}{c}\text { Antar } \\
\text { Kelompok } \\
\text { Dalam } \\
\text { kelompok } \\
\text { Total }\end{array}$ & 6,776 & 2 & 1,388 & 2,382 \\
& 69,201 & 116 &, 583 & \\
\hline
\end{tabular}

\section{Kadar air}

Pengeringan merupakan penghilangan kadar air dari suatu bahan. Faktor yang mempengaruhi pengeringan yaitu luas permukaan, suhu pengeringan, aliran udara, tekanan uap air, dan sumber energi yang digunakan dalam pengeringan. Pengeringan terjadi selama 30 hari. Pada hasil tersebut terdapat beberapa keadaan dimana terjadi kenaikan kadar air, tetapi masih dalam rentang 4\%. Kadar air dianggap stabil jika memiliki selisih $\pm 4 \%$. Konsentrasi pekat menghasilkan kadar air yang lebih rendah dibandingkan yang paling encer. Hal ini menunjukkan bahwa kandungan zat yang pekat menyebabkan cairan susah dievaporasikan, sehingga kecenderungan melalui filtrasi. Lumpur pekat mengikat kadar air sehingga cairan sulit untuk dievaporasikan (Huriwati $d k k$., 2016). Hasil pengukuran kadar air dapat dilihat pada Gambar 7. 


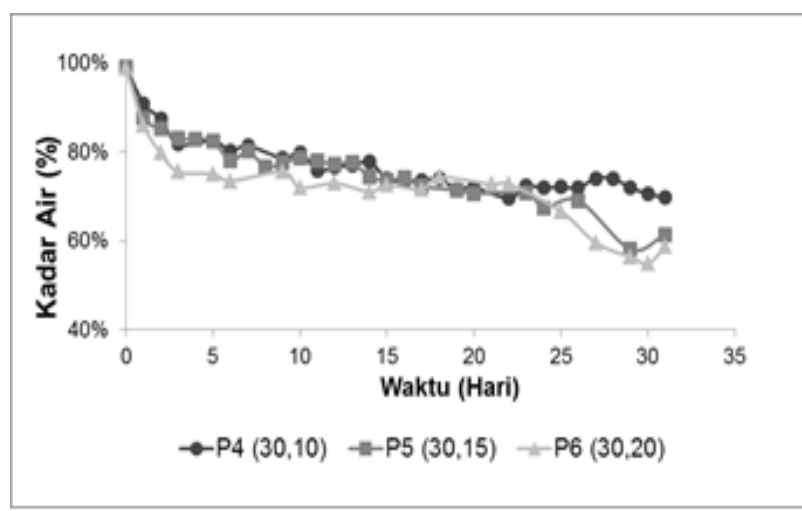

Gambar 7. Hasil Penurunan Kadar air

Pengeringan pada unit SSC tanpa pengaruh hujan dengan ketebalan lumpur $30 \mathrm{~cm}$ masih mengandung kadar $70 \%$ untuk konsentrasi TS $10 \mathrm{~g} / \mathrm{L}, 61 \%$ untuk $15 \mathrm{~g} / \mathrm{L}$, dan $59 \%$ untuk 20 $\mathrm{g} / \mathrm{L}$. Hal ini menandakan bahwa cake yang tertinggal belum dapat digunakan sebagai kompos. Waktu optimum pengurasaan yaitu, dimana cake telah mampu digunakan sebagai syarat kompos dengan mengandung kadar air $50 \%$. Selama 30 hari dapat menghilangkan kadar air sebesar 30\% untuk $10 \mathrm{~g} / \mathrm{L}, 39 \%$ untuk $15 \mathrm{~g} / \mathrm{L}$, dan $49 \%$ untuk $20 \mathrm{~g} / \mathrm{L}$, sehingga membutuhkan waktu \pm 6 minggu untuk menghasilkan cake sebagai syarat kompos jadi. Sehingga setelah 6 minggu unit SSC dikuras dan diisi kembali.

\section{Pengaruh Suhu Lumpur Terhadap Penyisihan TS dan TSS Filtrat}

Pengukuran suhu lumpur dilakukan untuk mengetahui seberapa besar pengaruh suhu terhadap penyisihan TS dan TSS. Suhu memiliki peranan penting dalam proses pengeringan karena meningkatkan laju evaporasi (Cofie $d k k .$, 2006). Suhu tinggi dengan kelembaban relatif rendah dan didukung oleh kecepatan angin akan meningkatkan jumlah total air yang dihilangkan melalui penguapan. Hasil pengukuran suhu lumpur dengan berbagai konsentrasi TS dapat dilihat pada Gambar 8.

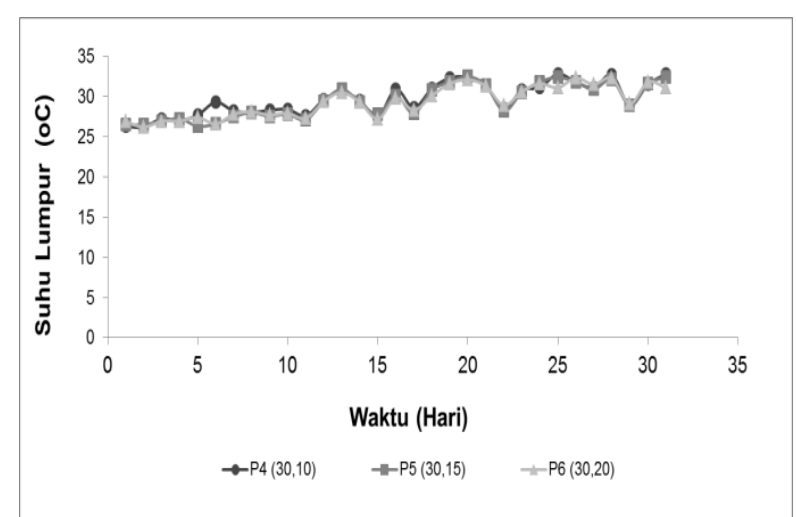

Gambar 8. Suhu Lumpur dengan berbagai Konsentrasi TS

Berdasarkan hasil pengukuran besarnya konsentrasi TS tidak mempengaruhi besarnya perubahan suhu lumpur. Hal ini dapat dilihat dari hasil yang saling berpotongan. Hasil uji statistik menggunakan Anova One Way (Tabel 3) dihasilkan bahwa suhu lumpur mempengaruhi besarnya penyisihan TS dan TSS pada unit SSC yang dibuktikan dengan derajat kepercayaan $<95 \%$ atau Sig $>5 \%$. Hal ini menunjukkan bahwa zat tersuspensi yang tertinggal pada media filter mempengaruhi besarnya evaporasi yang terjadi. Hasil uji pengaruh suhu terhadap penyisihan TS dan TSS melalui filtrat dapat dilihat pada Tabel 3.

Tabel 3. Hasil Uji Anova Pengaruh Suhu terhadap Penyisihan TS dan TSS

\begin{tabular}{|c|c|c|c|c|c|c|}
\hline & & Jumlah $\mathrm{R}^{2}$ & df & $\begin{array}{c}\mathrm{R} \text { rata- } \\
\text { rata }\end{array}$ & F & Sig \\
\hline $\begin{array}{c}\text { TS } \\
\text { Filtrat }\end{array}$ & $\begin{array}{c}\text { Antar } \\
\text { Kelom } \\
\text { pok } \\
\text { Dalam } \\
\text { kelomp } \\
\text { ok } \\
\\
\text { Total }\end{array}$ & $\begin{array}{c}135323155 \\
0,153 \\
180866179 \\
, 762 \\
153409772 \\
9,915 \\
\end{array}$ & $\begin{array}{c}44 \\
72 \\
116\end{array}$ & $\begin{array}{c}307552 \\
62,503 \\
251203 \\
0,274\end{array}$ & $\begin{array}{c}12,24 \\
3\end{array}$ & $\begin{array}{c}, 00 \\
0\end{array}$ \\
\hline $\begin{array}{c}\text { TSS } \\
\text { Filtrat }\end{array}$ & $\begin{array}{c}\text { Antar } \\
\text { Kelom } \\
\text { pok } \\
\text { Dalam } \\
\text { kelomp } \\
\text { ok } \\
\\
\text { Total }\end{array}$ & $\begin{array}{c}2966943,0 \\
72 \\
1771977,2 \\
36 \\
4738920,3 \\
08\end{array}$ & $\begin{array}{c}72 \\
116\end{array}$ & $\begin{array}{c}67430, \\
524 \\
24610, \\
795\end{array}$ & 2,740 & $\begin{array}{c}, 00 \\
0\end{array}$ \\
\hline
\end{tabular}




\section{KESIMPULAN}

1. Efisiensi penyisihan optimum melalui filtrat untuk TS sebesar $97 \%$ dan TSS sebesar $97,8 \%$.

2. Semakin besar konsentrasi TS yang dimasukkan pada unit SSC menyebabkan peningkatan efisiensi penyisihan TS, namun tidak menyebabkan peningkatan efisiensi TSS.

3. Semakin encer konsentrasi Total Solid (TS), maka semakin cepat proses dewatering dengan waktu optimum yang digunakan adalah \pm 6 minggu tanpa pengaruh hujan.

\section{Ucapan terima kasih}

Penulis mengucapkan terimakasih kepada pihak DKRTH dan IPLT Keputih, Surabaya yang telah memberikan izin dalam proses pengambilan sampel.

\section{DAFTAR PUSTAKA}

Bassan, M., Dodane, P.H., Strande, L. (2014). Faecal Sludge Management. London: IWA Publishing.

Cofie, O. O., Agbottah, S., Strauss, M., Esseku, H., Montangero, A., Awuah, E., Kone, D. (2006). Solid-Liquid Separation of Faecal Sludge Using Drying Beds in Ghana: Implications for Nutrient Recycling in Urban Agriculture. Water Research, 40(1), $75-82$.

Dian, G., Herumurti, W. (2016). Evaluasi Kinerja Instalasi Pengolahan Lumpur Tinja (IPLT) Keputih, Surabaya. JURNAL TEKNIK ITS, 5(1).

Huriawati, F., Yuhanna, W.L., Mayasari,T. (2016). Pengaruh Metode Pengeringan Terhadap Kualitas Serbuk Seresah Enhalus acoroides dari Pantai Tawang Pacitan. Bioeksperimen.2(1)
Kone, D., Strauss, M. (2004). Low-cost Options for Treating Faecal Sludges (FS) in Developing Countries Challenges and Performance. Paper Presented to the 9th International IWA Specialist Group Conference on Wetlands Systems for Water Pollution Control; and to the 6th International IWA Specialist Group Conference on Waste Stabilisation Ponds.

Koottatep, T., Surinkul, N., Polprasert, C., Kamal, A. S. ., Kone, D., Montangero, A. (2005). Treatment of Septage in Constructed Wetlands in Tropical Climate: Lessons Learnt from Seven Years of Operation. Water Science and Technology, 51(9), 21-28.

Standart Method. (2006). Standard Methods for Examination of Water and Wastewater: 21th Edition. Washington DC: American Public Health Association Publisher.

Sudarmadji, Hamdi. (2013). Tangki Septik dan Peresapannya sebagai Sistem Pembuangan Air Kotor di Permukiman Rumah Tinggal Keluarga. PILAR Jurnal Teknik Sipil, 9(2). 